\title{
FAKTOR-FAKTOR RISIKO STROKE PADA PENYAKIT GINJAL KRONIK STADIUM V YANG MENJALANI HEMODIALISIS
}

\author{
RISK FACTORS OF STROKE IN STAGE V CHRONIC KIDNEY DISEASE WHO \\ UNDERWENT HEMODIALYSIS
}

Susanti Dwi Ariani, * Dodik Tugasworo, *Maria Imakulata Widiastuti Samekto*

\section{ABSTRACT}

Introduction: Chronic kidney disease (CKD) and end-stage renal disease are associated with a significantly increased risk of stroke. Incidence and mortality of stroke in CKD patients is higher rather than among the general population. Stroke in hemodialysis patients is also associated with high mortality.

Aims: To analyze risk factors that have a relationship with the occurrence of stroke in patients with stage V CKD who underwent hemodialysis in Dr. Kariadi Hospital, Semarang.

Method: A case control with retrospective cohort study of patients diagnosed with stage V CKD undergoing hemodialysis in Dr. Kariadi Hospital, Semarang, from March 2016 to August 2017. Subject was divided into case group, who experienced stroke, and control group, who did not experience stroke. Bivariate analysis was performed with Chi-square test, multivariate analysis with logistic regression test and rasio Odds.

Results: There were 140 subjects with stage V CKD, 70 subjects in each groups. In case group, $85.7 \%$ experienced ischemic stroke while the rest hemorrhagic stroke. The duration of hemodialysis was related to the incidence of stroke. In multivariate analysis, patients with diabetes mellitus were more likely to have a stroke by 0.14 times compared to patients who did not have diabetes mellitus, and patients who underwent hemodialysis $>12$ months, were more likely to have a stroke 4.05 times greater than patients who underwent hemodialysis $<12$ months.

Discussion: There is a relationship between diabetes mellitus and duration of hemodialysis with the occurrence of ischemic stroke, in stage V CKD patients who underwent hemodialysis.

Keywords: Chronic kidney disease, hemodialysis, stroke

\section{ABSTRAK}

Pendahuluan: Penyakit ginjal kronik (PGK) dan penyakit ginjal stadium akhir terkait dengan peningkatan risiko yang signifikan dari stroke. Insiden dan mortalitas stroke pada pasien PGK lebih tinggi dibandingkan populasi umum. Stroke pada pasien dialisis juga dihubungkan dengan mortalitas yang tinggi.

Tujuan: Untuk menganalisis faktor-faktor risiko yang memengaruhi terjadinya stroke pada pasien dengan PGK stadium V yang menjalani hemodialisis (HD) di RSUP Dr. Kariadi, Semarang.

Metode: Penelitian kasus kontrol dengan pendekatan kohort retrospektif terhadap pasien penyakit ginjal kronik stadium V yang menjalani HD di RSUP Dr. Kariadi, Semarang dari bulan Maret 2016 hingga Agustus 2017. Subjek dibagi ke dalam kelompok kasus, yaitu yang mengalami stroke dan kelompok kontrol yang tidak mengalami stroke. Dilakukan analisis bivariat dengan uji Chi-square dan analisis multivariat dengan uji regresi logistik serta rasio Odds.

Hasil: Didapatkan 140 subjek dengan PGK stadium V yang masing-masing kelompok terdiri dari 70 orang. Pada kelompok kasus, sebanyak $85,7 \%$ adalah stroke iskemik dan sisanya stroke hemoragik. Lama HD berhubungan dengan kejadian stroke. Pada uji multivariat, subjek yang menderita diabetes melitus (DM) berisiko mengalami stroke sebesar 0,14 kali dibandingkan yang tidak DM dan subjek yang menjalani $\mathrm{HD} \geq 12$ bulan berisiko mengalami stroke 4,05 kali lebih besar dibandingkan yang menjalani $\mathrm{HD}<12$ bulan.

Diskusi: Terdapat pengaruh faktor risiko DM dan lama hemodialisis terhadap kejadian stroke iskemik pada pasien PGK stadium $V$ yang menjalani HD.

Kata kunci: Hemodialisis, penyakit ginjal kronik, stroke

*Bagian/KSM Neurologi FK Universitas Diponegoro/RSUP Dr. Kariadi, Semarang. Korespondensi: susantidwiariani@yahoo.com.

\section{PENDAHULUAN}

Stroke menempati urutan ketiga penyebab kematian setelah penyakit jantung dan kanker. ${ }^{1}$ Data di Indonesia menunjukkan kecenderungan peningkatan kasus stroke baik dalam hal kematian, kejadian maupun kecacatan. ${ }^{2}$ Pada tahun 2013, prevalensi penyakit stroke meningkat seiring dengan bertambahnya umur, tertinggi pada umur $\geq 75$ tahun dan prevalensi stroke yang terdiagnosis, sama tinggi pada laki-laki dan perempuan. ${ }^{3}$

Insiden dan prevalensi penyakit ginjal kronik (PGK) meningkat seiring dengan usia dan pasien 
PGK merupakan populasi risiko sangat tinggi untuk berkembangnya stroke. PGK dapat meningkatkan risiko insiden stroke independen dari faktor risiko stroke konvensional. Proses patologis umumnya termasuk anemia, hemosistein, nitrat oksida, stres oksidatif, inflamasi dan kondisi yang menyebabkan koagulasi dihubungkan dengan berkembangnya stroke tentunya pada PGK. ${ }^{4}$

Insiden stroke iskemik lebih besar daripada stroke hemoragik oleh karena faktor risiko stroke iskemik lebih banyak ditemukan pada pasien dengan PGK, seperti tromboemboli, aterosklerosis, inflamasi, dan kardioemboli. Demikian pula percepatan aterosklerosis merupakan faktor risiko utama terjadinya stroke pada pasien PGK stadium akhir.

Penelitian di Jepang, 39\% stroke iskemik dan $35 \%$ hemoragik terjadi selama atau dalam waktu 30 menit dari hemodialisis (HD), menunjukkan bahwa pengobatan itu sendiri dapat memediasi risiko stroke. ${ }^{5-6}$

Adapun PGK stadium akhir dikaitkan dengan hipertensi bleeding diathesis dan terapi antikoagulan heparin selama terapi dialisis menyebabkan fungsi trombosit abnormal, yaitu respons trombosit terhadap cedera pembuluh darah, termasuk aktivasi trombosit, perekrutan, adhesi dan agregasi yang rusak, yang semua faktor tersebut berpotensi meningkatkan risiko stroke hemoragik. ${ }^{7}$

\section{TUJUAN}

Untuk mengetahui faktor-faktor risiko yang memengaruhi terjadinya stroke pada pasien dengan penyakit ginjal kronik stadium $\mathrm{V}$ yang menjalani hemodialisis di RSUP Dr. Kariadi, Semarang.

\section{METODE}

Penelitian kasus kontrol dengan pendekatan kohort retrospektif terhadap pasien penyakit ginjal kronik stadium V yang menjalani HD di RSUP Dr. Kariadi, Semarang dari bulan Maret 2016 hingga Agustus 2017. Subjek dibagi ke dalam kelompok kasus, yaitu yang mengalami stroke dan kelompok kontrol yang tidak mengalami stroke. Diagnosis stroke ditegakkan secara klinis dan pemeriksaan CT scan kepala. Kriteria eksklusi adalah yang pernah mengalami stroke sebelumnya atau data tidak lengkap.

Pengumpulan data sekunder berdasarkan rekam medis pasien yang meliputi data demografi, klinis, laboratorium, serta lama dan frekuensi hemodialisis. Status gizi dinilai berdasarkan perhitungan indeks massa tubuh (IMT), dengan batas ambang normal untuk laki-laki adalah 20,1-25,0 dan untuk perempuan 18,7-23,8. ${ }^{8}$ Kriteria anemia menurut National Cancer Institute adalah kadar hemoglobin $<14$ gr\% (laki-laki) dan $<12$ gr $\%$ (perempuan). ${ }^{9}$

Dilakukan analisis univariat untuk mengetahui proporsi pada kelompok kasus dan kontrol serta analisis bivariat dengan uji Chi-square antara faktor risiko dan variabel dependen pada kelompok subjek dengan $\alpha=0,05$. Adapun analisis multivariat dengan uji regresi logistik untuk menentukan variabel sebagai faktor risiko yang benar-benar berpengaruh terhadap variabel dependen, dilengkapi nilai rasio Odds (RO) pada interval kepercayaan (IK) 95\%.

\section{HASIL}

Didapatkan 140 subjek dengan PGK stadium V yang masing-masing kelompok terdiri dari 70 orang. Pada kelompok kasus, sebanyak 85,7\% (60 orang) adalah stroke iskemik dan sisanya stroke hemoragik (10 orang). Selanjutnya dilakukan analisis terpisah antara subjek dengan stroke iskemik dan hemoragik dibandingkan 70 subjek kontrol (Tabel 1).

Pada kedua kelompok, mayoritas berusia $>55$ tahun $(65 \%)$, laki-laki $(>60 \%)$, serta memiliki status gizi tidak normal $(61,6 \%)$. Subjek yang mengalami stroke (Tabel 1), terutama mempunyai komorbid penyakit hipertensi $(80,8 \%)$, diabetes melitus (DM) $(69,2 \%)$, dan penyakit jantung $(53,1 \%)$. Demikian pula hampir seluruh subjek mengalami anemia (93,8\%), diikuti hiperurisemia $(64,6 \%)$, dan hipoalbuminemia $(60,8 \%)$.

Mayoritas subjek $(93,8 \%)$ rutin menjalani HD dengan frekuensi 2 kali dalam seminggu, sebanyak $53,1 \%$ telah menjalani HD kronik selama $\geq 12$ bulan, serta paling lama subjek menjalani HD selama 60 bulan. Berdasarkan karakteristik hemodialisis yang dijalani, lama HD juga memiliki hubungan yang bermakna dengan kejadian stroke $(\mathrm{p}=0,00)$. 
Tabel 1. Karakteristik Subjek berdasarkan Kejadian Stroke Iskemik $(\mathbf{n}=130)$

\begin{tabular}{|c|c|c|c|c|}
\hline \multirow{2}{*}{ Variabel } & \multirow{2}{*}{ Rerata \pm SD } & \multicolumn{2}{|c|}{ Stroke Iskemik } & \multirow{2}{*}{ p } \\
\hline & & Ya & Tidak & \\
\hline $\begin{array}{l}\text { Usia } \\
\bullet \leq 55 \text { tahun } \\
\cdot>55 \text { tahun } \\
\text { Jenis kelamin }\end{array}$ & $\begin{array}{l}57 \pm 43,8 \\
73 \pm 56,2\end{array}$ & $\begin{array}{l}21 \\
39\end{array}$ & $\begin{array}{l}36 \\
34\end{array}$ & 0,06 \\
\hline $\begin{array}{l}\text { - Perempuan } \\
\text { - Laki-laki } \\
\text { Status gizi }\end{array}$ & $\begin{array}{l}54 \pm 41,5 \\
76 \pm 58,5\end{array}$ & $\begin{array}{l}22 \\
38\end{array}$ & $\begin{array}{l}32 \\
38\end{array}$ & 0,29 \\
\hline $\begin{array}{l}\text { - Tidak normal } \\
\text { - Normal } \\
\text { Hipertensi }\end{array}$ & $\begin{array}{l}91 \pm 70 \\
39 \pm 30\end{array}$ & $\begin{array}{l}37 \\
23\end{array}$ & $\begin{array}{l}54 \\
16\end{array}$ & 0,05 \\
\hline $\begin{array}{l}\text { - Ya } \\
\text { - Tidak } \\
\text { DM }\end{array}$ & $\begin{array}{c}105 \pm 80,8 \\
25 \pm 19,2\end{array}$ & $\begin{array}{c}51 \\
9\end{array}$ & $\begin{array}{l}54 \\
16\end{array}$ & 0,26 \\
\hline $\begin{array}{l}\text { - Ya } \\
\text { - Tidak }\end{array}$ & $\begin{array}{l}87 \pm 66,9 \\
43 \pm 33,1\end{array}$ & $\begin{array}{l}30 \\
30\end{array}$ & $\begin{array}{l}57 \\
13\end{array}$ & $0,00 *$ \\
\hline $\begin{array}{l}\text { Dislipidemia } \\
\text { - Ya } \\
\text { - Tidak }\end{array}$ & $\begin{array}{l}90 \pm 69,2 \\
40 \pm 30,8\end{array}$ & $\begin{array}{l}40 \\
20\end{array}$ & $\begin{array}{l}50 \\
20\end{array}$ & 0,56 \\
\hline $\begin{array}{l}\text { Penyakit jantung } \\
\text { - Ya } \\
\text { - Tidak } \\
\text { IHD }\end{array}$ & $\begin{array}{l}69 \pm 53,1 \\
61 \pm 46,9\end{array}$ & $\begin{array}{l}39 \\
21\end{array}$ & $\begin{array}{l}30 \\
40\end{array}$ & $0,01 *$ \\
\hline $\begin{array}{l}\text { - Ya } \\
\text { - Tidak } \\
\text { HHD }\end{array}$ & $\begin{array}{l}35 \pm 26,9 \\
95 \pm 73,1\end{array}$ & $\begin{array}{l}17 \\
43\end{array}$ & $\begin{array}{l}18 \\
52\end{array}$ & 0,74 \\
\hline $\begin{array}{l}\text { - Ya } \\
\text { - Tidak } \\
\text { CHF }\end{array}$ & $\begin{array}{c}23 \pm 17,7 \\
107 \pm 82,3\end{array}$ & $\begin{array}{l}16 \\
44\end{array}$ & $\begin{array}{c}7 \\
63\end{array}$ & $0,01 *$ \\
\hline $\begin{array}{l}\text { - Ya } \\
\text { - Tidak } \\
\text { Kadar ureum }\end{array}$ & $\begin{array}{c}12 \pm 9,2 \\
118 \pm 90,8 \\
154,12 \pm 78,49\end{array}$ & $\begin{array}{c}6 \\
54\end{array}$ & $\begin{array}{c}6 \\
64\end{array}$ & 0,78 \\
\hline Kadar kreatinin & $11,92 \pm 19,59$ & & & 0,52 \\
\hline $\begin{array}{l}\text { LFG } \\
\text { Anemia }\end{array}$ & $8,44 \pm 4,94$ & & & 0,29 \\
\hline $\begin{array}{l}\text { Anemia } \\
\text { - Ya } \\
\text { - Tidak } \\
\text { Hiperurisemia }\end{array}$ & $\begin{array}{c}122 \pm 93,8 \\
8 \pm 6,2\end{array}$ & $\begin{array}{c}57 \\
3\end{array}$ & $\begin{array}{c}65 \\
5\end{array}$ & $\begin{array}{l}0,99 \\
0,61\end{array}$ \\
\hline $\begin{array}{l}\text { - Ya } \\
\text { - Tidak } \\
\text { Hipoalbuminemia }\end{array}$ & $\begin{array}{l}84 \pm 64,6 \\
46 \pm 35,4\end{array}$ & $\begin{array}{l}37 \\
23\end{array}$ & $\begin{array}{l}47 \\
23\end{array}$ & 0,81 \\
\hline $\begin{array}{l}\text { - Ya } \\
\text { - Tidak } \\
\text { Frekuensi } \\
\text { hemodialisis }\end{array}$ & $\begin{array}{l}79 \pm 60,8 \\
51 \pm 39,2\end{array}$ & $\begin{array}{l}45 \\
15\end{array}$ & $\begin{array}{l}34 \\
36\end{array}$ & $0,02 *$ \\
\hline $\begin{array}{l}\text { - }>2 \text { kali/minggu } \\
\text { - } 2 \text { kali/minggu } \\
\text { Lama } \\
\text { hemodialisis }\end{array}$ & $\begin{array}{c}8 \pm 6,2 \\
122 \pm 93,8\end{array}$ & $\begin{array}{c}5 \\
55\end{array}$ & $\begin{array}{c}3 \\
67\end{array}$ & 0,34 \\
\hline $\begin{array}{l}\text { - } \geq 12 \text { bulan } \\
\text { - }<12 \text { bulan }\end{array}$ & $\begin{array}{c}69 \pm 53,1 \\
61 \pm 46,90\end{array}$ & $\begin{array}{l}43 \\
17\end{array}$ & $\begin{array}{l}26 \\
44\end{array}$ & $0,00 *$ \\
\hline
\end{tabular}

IHD: ischemia heart disease; HHD: hypertensive heart disease; CHF: chronic heart failure; LFG: laju filtrasi glomerulus; *Uji Chi-square.
Dilakukan analisis multivariat regresi logistik terhadap faktor-faktor risiko yang memengaruhi kejadian stroke (Tabel 2), maka variabel yang paling berpengaruh ialah DM dan lama menjalani HD. Subjek yang memiliki DM kemungkinan untuk mengalami stroke sebesar 0,14 kali dibandingkan yang tidak memiliki DM, serta subjek yang telah menjalani $\mathrm{HD} \geq 12$ bulan memiliki kemungkinan untuk mengalami stroke 4,05 kali lebih besar dibandingkan yang menjalani HD $<12$ bulan.

\section{PEMBAHASAN}

Dari 70 subjek penelitian ditemukan bahwa proporsi stroke iskemik lebih banyak dibandingkan stroke hemoragik, yaitu masing-masing 85\% dan $15 \%$. Hal ini sesuai dengan Arnold dkk yang melaporkan bahwa penyakit ginjal stadium akhir dikaitkan dengan peningkatan risiko stroke yang signifikan, yaitu stroke iskemik (87\%) dan stroke hemoragik (13\%). ${ }^{7}$

Penelitian ini mendapatkan mayoritas subjek berusia $>55$ tahun. Selinger $\mathrm{dkk}$ melaporkan peningkatan usia berisiko mengalami stroke pada PGK 6 kali lebih tinggi dibandingkan dengan populasi umum. ${ }^{10} \mathrm{Hal}$ ini sesuai dengan Fabjan dkk bahwa pasien PGK stadium akhir meningkat pada orang-orang yang berusia $\geq 55$ tahun. ${ }^{11}$ Demikian pula terdapat risiko stroke 5-10 kali lebih besar daripada fungsi ginjal normal. Faktor usia menyebabkan perubahan fisiologi sistem kardiovaskuler, terjadi penurunan elastisitas pembuluh darah, dan meningkatkan kekakuan pembuluh darah arteri. ${ }^{11}$

Subjek dengan stroke iskemik pada penelitian ini terutama laki-laki, sedangkan pada stroke hemoragik proporsi antara laki-laki dan perempuan adalah sama. Temuan ini sesuai dengan Pahwa dkk, namun berbeda dengan Selinger dkk, bahwa kejadian stroke lebih tinggi pada perempuan dibandingkan laki-laki. ${ }^{6,5,13}$ Saeed dkk melaporkan bahwa PGK terkait dengan risiko peningkatan stroke hemoragik pada laki-laki dan stroke iskemik pada perempuan, yang menunjukkan bahwa hubungan antara PGK dan subtipe stroke mungkin spesifik untuk jenis kelamin. ${ }^{14}$

Semua subjek penelitian ini memiliki status gizi yang tidak normal. Ankur J dkk melaporkan 
Tabel 2. Hasil Analisis Multivariat Regresi Logistik

\begin{tabular}{|c|c|c|c|c|c|}
\hline \multirow{2}{*}{ Variabel } & \multirow{2}{*}{ Koefisien } & \multirow{2}{*}{ p } & \multirow[t]{2}{*}{$\operatorname{Exp}(B)$} & \multicolumn{2}{|c|}{ IK95\% } \\
\hline & & & & Min & Maks \\
\hline DM & $-1,98$ & $\mathbf{0 , 0 0}$ & 0,14 & 0,52 & 0,37 \\
\hline Hipoalbuminemia & 0,40 & 0,48 & 1,49 & 0,49 & 4,56 \\
\hline HHD & 0,27 & 0,66 & 1,30 & 0,40 & 4,25 \\
\hline Lama HD & 1,39 & $\mathbf{0 , 0 1}$ & 4,05 & 1,37 & 12,03 \\
\hline
\end{tabular}

DM: diabetes melitus; HHD: hypertensive heart desease; HD: hemodialisis.

hubungan positif antara obesitas dan kejadian stroke pada pasien PGK, yaitu obesitas berhubungan dengan peningkatan risiko hipertensi, DM, dan penyakit jantung. ${ }^{15-16}$ Studi di Jepang menyatakan adanya hubungan linier antara peningkatan IMT dengan stroke iskemik dan stroke hemoragik. Terganggunya sistem neurohumoral seperti aktivasi sistem nervus simpatetik dan sistem renin angiotensin aldosteron (RAA) yang muncul pada gangguan ginjal terintegrasi berdampak obesitas pada penyakit serebrovaskuler termasuk stroke. ${ }^{17}$

Pada penelitian ini ditemukan bahwa hipertensi merupakan faktor risiko tradisional yang banyak didapati pada stroke iskemik (85\%) dan stroke hemoragik (100\%). Sesuai dengan Sellinger dkk, hipertensi terkait dengan peningkatan risiko stroke pada PGK stadium akhir.

Hipertensi merupakan komponen utama penyebab dan hasil dari kerusakan ginjal. Hipertensi dapat secara sinergis meningkatkan risiko stroke selama HD dimana terjadi induksi iskemik dan terdapatnya instabilitas hemodinamik selama ultrafiltrasi pada proses HD. Peningkatan tekanan darah selama HD memiliki risiko yang tinggi. HD memiliki kecenderungan terjadinya perubahan tekanan darah, hipertensi intradialitik merupakan komplikasi yang terjadi selama HD. Gangguan pada sisitem RAA, perubahan hematokrit dan level serum elektrolit atau disfungsi autonomik berkontribusi terhadap berkembangnya hipertensi intradialitik..$^{8,18-20}$

Hasil uji multivariat faktor risiko DM ternyata memiliki pengaruh yang lebih signifikan untuk terjadinya stroke. Pada stroke iskemik terdapat peranan hiperglikemi dalam proses atherosklerosis yaitu gangguan metabolisme berupa akumulasi sorbitol pada dinding pembuluh darah arteri. Hal ini menyebabkan gangguan osmotik dan kandungan air didalam sel yang dapat mengakibatkan kurangnya oksigenisasi.Terjadinya orthostasis dapat memediasi kerusakan otak setelah HD khususnya pasien DM.

Chun Yu Lin dkk menyatakan bahwa DM dapat ditemukan pada kejadian stroke hemoragik. ${ }^{21} \mathrm{DM}$ menginduksi perubahan struktural dan fungsional pada pembuluh darah kecil yang menyebabkan nekrosis fibrinoid dinding pembuluh darah dan formasi miroaneurisma, akibat perubahan dinding pembuluh darah pada pasien DM menyebabkan terjadi hematom..$^{21-22}$

Dalampenelitian ini, didapatihipoalbuminemia memiliki pengaruh terhadap kejadian stroke iskemik pada pasien PGK stadium V yang menjalani HD. Sesuai dengan data dari the National Health Epidemiology Follow up Study (NHEFS) yang menyatakan bahwa serum albumin rendah dapat menjadikan indikator dari faktor-faktor yang memengaruhi atherosklerosis. Konsentrasi albumin berpengaruh pada fungsi trombosit, kekentalan darah, transportasi lemak bebas dan antioksidan. Iseki $\mathrm{dkk}$, telah melaporkan peningkatan insiden stroke hemoragik pada pasien dengan PGK yang menjalani HD memiliki prevalensi yang tinggi dari hipertensi, malnutrisi protein dan hipoalbuminemia, yang mana berefek langsung pada deformabilitas eritrosit dan disfungsi endotel. ${ }^{10,23-25}$

Subjek yang mengalami stroke pada pasien dengan PGK stadium V yang menjalani HD memiliki dislipidemia sebanyak 66,6\% (stroke iskemik) dan $67,5 \%$ (stroke hemoragik), temuan ini sesuai dengan pedoman K/DOQI (the Kidney Disease Outcomes Quality Initiative Guidelines) tentang dislipidemia pada pasien PGK yang telah melaporkan bahwa $55,7 \%$ pasien HD memiliki kadar LDL $>100 \mathrm{mg} / \mathrm{dl}$. 
Komponen dislipidemia yang berperan yakni kadar HDL yang rendah dan kadar LDL yang tinggi dimana keduanya mempercepat atherosklerosis pembuluh darah koroner dan otak. Dislipidemia menyebabkan abnormalitas lipoprotein pada plasma sehingga lipid berikatan dengan matriks ekstraseluler kemudian akan terjadi peningkatan ROS yang mengakibatkan penyakit jantung dan fibrosis ginjal melalui aktivasi angiotensi II. Selain itu juga akan terjadi apoptosis sel endotel sehingga terjadi penyakit pembuluh darah otak dan penyakit kardiovaskuler. ${ }^{18,26}$

Pada penelitian ini, ternyata penyakit jantung memiliki pengaruh terhadap terjadinya stroke pada pasien dengan PGK yang menjalani HD. HHD memiliki nilai yang signifikan untuk terjadinya stroke. Berbeda dengan penelitian yang dilakukan oleh Karbasi dkk yang melaporkan penyakit jantung yang ditemukan pada PGK stadium $V$ yang menjalani HD antara lain CAD 40\% dan 85\% mengalami gangguan pada struktur dan fungsi jantung. ${ }^{14}$ Pasien PGK stadium $\mathrm{V}$ terjadi percepatan penyakit atherosklerosis dari pembuluh darah serebral dan meningkatkan risiko yang tinggi untuk terjadinya stroke. ${ }^{27}$

Hampir seluruh subjek mengalami anemia. Temuan ini sesuai dengan studi ARIC (Atherosclerosis Risk in Communities Study) tahun 2003 yang menunjukkan hubungan antara anemia dan stroke pada pasien PGK. ${ }^{28}$ Peningkatan risiko stroke akibat anemia berat pada PGK stadium $\mathrm{V}$ yang menjalani HD secara biologis dapat melalui efek langsung dari kapasitas pembawa oksigen yang rendah pada daerah otak, sehingga terjadi perfusi yang buruk. Penurunan produksi eritropoietin akibat penurunan fungsi ginjal dapat menyebabkan anemia. Anemia itu sendiri dapat meningkatkan risiko stroke dengan menginduksi aterosklerosis melalui peningkatan stres oksidatif dan hipertrofi ventrikel kiri pada pasien PGK. ${ }^{29}$

Pada subjek yang mengalami stroke iskemik, didapatkan 52,9\% subjek mengalami hiperurisemia. Lorenzo dkk melaporkan bahwa penyakit ginjal kronik dan hiperurisemia berkaitan dengan peningkatan risiko dan prognosis yang buruk pada stroke iskemik akut. ${ }^{31}$ Asam urat juga menginduksi stres oksidatif dan disfungsi endotel, sehingga menyebabkan hipertensi sistemik dan hipertensi glomerulus. ${ }^{30-31}$

Penurunan laju filtrasi glomerulus (LFG) berkaitan dengan prevalensi yang tinggi untuk terjadinya stroke. Boss dkk melaporkan bahwa penurunan LFG menyebabkan penyakit pembuluh darah kecil tidak hanya pada ginjal tetapi juga pada otak. $^{32}$ Penurunan LFG menyebabkan disfungsi trombosit, sehingga terjadi stroke hemoragik. ${ }^{32}$ Adapun LFG $\leq 60 \mathrm{~mL} /$ menit $/ 1,73 \mathrm{~m}^{2}$ merupakan prediktor yang kuat dan signifikan terhadap kejadian stroke iskemik. ${ }^{33}$

Seluruh subjek penelitian ini juga didapatkan memiliki kadar ureum dan kreatinin yang tinggi. Kondisi uremia menyebabkan defisiensi eritropoietin yang menyebabkan anemia hingga terjadi penurunan oksigenasi keotak dan menyebabkan stroke iskemik. ${ }^{7}$ Demikian pula uremia mengganggu ikatan antara reseptor IIb-IIa dan faktor von willebrand yang mengarah pada gangguan agregasi trombosit, sehingga terjadi stroke hemoragik. ${ }^{34}$ Raymond dkk melaporkan bahwa peningkatan risiko stroke pada penyakit ginjal terkait dengan kadar kreatinin $>1,3 \mathrm{mg} / \mathrm{dl}$. Bukti fisiologis telah menunjukkan bahwa gangguan ginjal sendiri dapat meningkatkan kemungkinan terjadinya stroke. ${ }^{35}$

Pada penelitian ini, pasien yang menjalani HD $\geq 12$ bulan memiliki risiko 4,05 kali untuk mengalami stroke iskemik. Hal ini dikarenakan lama HD mencerminkan lama pasien terpapar dengan kondisi uremik yang menyebabkan percepatan aterosklerosis, sehingga terjadi stroke. Ezzat dkk dalam studinya menunjukkan pengaruh yang signifikan antara durasi HD terhadap kejadian stroke. Kebanyakan pasien PGK yang menjalani HD memiliki durasi dialisis lebih dari 1 tahun..$^{23}$ Perdarahan diatesis dan pemberian heparin rutin selama HD dapat meningkatkan risiko stroke hemoragik. Pada studi ini, insiden stroke paling besar pada 2 tahun setelah inisiasi terapi HD. Penurunan nilai tekanan darah selama ultrafiltrasi dapat menyebabkan gangguan perfusi sehingga menyebabkan stroke iskemik. ${ }^{36}$

Mayoritas subjek pada penelitian ini menjalani HD 2 kali seminggu. Toyoda dkk menemukan bahwa 
stroke iskemiklebih umum terjadi selama atau segera setelah prosedur dialisis dibandingkan dengan stroke hemoragik. ${ }^{6}$ Frekuensi HD terkait kadar ureum yang tinggi secara terus menerus, yaitu kondisi uremik tersebut menyebabkan percepatan kalsifikasi pembuluh darah, meningkatkan aterosklerosis karotis, kecenderungan protrombotik, dan gangguan autoregulasi serebral. ${ }^{37}$

Penelitian ini mempunyai keterbatasan, yaitu jumlah subjek yang mengalami stroke hemoragik hanya sedikit, sehingga data tidak didapat dianalisis. Demikian pula data rekam medis banyak yang tidak lengkap, terutama terkait faktor risiko dislipidemia, riwayat penyakit dahulu, seperti DM atau hipertensi, serta faktor-faktor risiko non-tradisional.

\section{KESIMPULAN}

Terdapat pengaruh faktor risiko diabetes melitus dan lama hemodialisis terhadap kejadian stroke iskemik pada pasien PGK stadium V yang menjalani HD.

\section{DAFTAR PUSTAKA}

1. Misbach J. Stroke: aspek diagnostik, patofisiologi, manajemen. Badan Penerbit FKUI. Jakarta; 2011.

2. Kelompok Studi Perhimpunan Dokter Spesialis Saraf Indonesia (PERDOSSI). Guideline stroke 2011. Jakarta: PERDOSSI; 2011.

3. Badan Penelitian dan Pengembangan Kesehatan Kementerian Kesehatan RI. Riset kesehatan dasar. Jakarta; 2013.

4. Kim SJ, Bang OY. Antiplatelettherapy for preventing stroke in patients with chronic kidney disease. Management stroke in chronic kidney disease. Nephrol. 2013;179:119-29.

5. Power A. Stroke in dialysis and chronic kidney disease. Blood Purification J. 2013;36(3-4):179-83.

6. Toyoda K, Ninomiya T. Stroke and cerebrovasculer disease in patient with chronic kidney disease. Lancet Neurol. 2014;13(8):823-33.

7. Arnold J, Sims D, Ferro C. Modulation of stroke risk in chronic kidney disease. ClinKidney J. 2016;9(1):29-38.

8. Kementrian kesehatan Republik Indonesia. Pedoman praktis memantau status gizi dewasa. Direktorat Jenderal Kesehatan Masyarakat: Direktorat Gizi Masyarakat; 2011.

9. Oehandian A. Pendekatan klinis dan diagnosa anemia. Continuing Medical Education. 2012;39(6):407-12.

10. Seliger SL, Gillen DL, Longstreth WT, Kestenbaum
B, Stehman-Breen CO. Elevated risk of stroke among patients with end-stage renal disease. Kidney Intl. 2003;64(2):603-9.

11. Fabjan TH, Hojs R. Renal dysfunction and ischemic stroke. European J Internal Med. 2014;25(1):18-24.

12. Wu CL, Tsai CC, Kor CT, Tarng DC, Lian IB, Yang $\mathrm{TH}$, dkk. Stroke and risks of development and progression of kidney disease and end stage renal disease: a nationwide population-based cohort study. Plos One J. 2016;11(6):e0158533.

13. Pahwa K, Ila P. Risk of stroke in chronic kidney disease. J Advance Res BiolSci. 2012;4(1):38-40.

14. Saeed T, Karbasi R, Saburi A. Clinical assosiation between renal dysfunction and vascular events. ARYA Atheroscler. 2013;9(3):203-8.

15. Jindal A, Whaley-Connell A, Sowers JR. Obesity and heart failure as a media of the cerebrorenal interaction. Nephrol. 2013;179:15-23.

16. Strazzulo P, D'Elia L, Cairella G, Garbagnati F, Cappucio FP, Scalfi L. Excess body weight and incidence of stroke: metaanalysis of prospective studies with 2 million participants. Stroke. 2010;41(5):e418-26.

17. Yatsuya H, Toyoshima H, Yamagishi K, Tamakoshi K, Taguri M, Harada A, dkk. Japan Arteriosclerosis Longitudinal Study (JALS) group body masss index and risk of stroke and myocardial infarction in a relatively lean population: metaanalysis of 16 Japanese cohort using individual data. Circ Cardiovasc Qual Outcomes. 2010;3(5):498-505.

18. Tedla F, Brar A, Browne, Brown C. Hypertension in chronic kidney disease: navigating the evidence. Int $\mathrm{J}$ Hypertension. 2011;2011:1-9.

19. Han SS, Ryu DR, Joo KW, Lim CS, Kim YL, Kang SW, dkk. Risk of stroke in elderly dialysis patients. J Korean Med Sci. 2017;32(9):1460-7.

20. Peter N, Jula K. Mechanisms and treatment of intradialytic hypertension. Blood Purif. 2016;41(13):188-93.

21. Lin CY, Chien CC, Chen HA, Su FM, Wang JJ, Wang CC,dkk. The impact of comorbidity on survival after hemorrhagic stroke among dialysis patients: a nationwide population-based study. BMC Nephrology. 2014;15(1):186.

22. Findlay MD, Thomson PC, Fulton RL, Solbu MD, Jardine AG, Patel RK, dkk. Risk factors of ischemic stroke and subsequent outcone in patients receiving hemodialysis. Stroke. 2015;46(9):2477-81.

23. Elwan ME, El Sheikh WM, El Shereef AM, El Kapany RA, Al Naggar EA. Cerebrovaskular stroke in chronic kidney disease. Menoufilia Med J. 2014;27(4):740-7.

24. Saeed F, Kousar N, Qureshi K, Laurence TN.A review of risk factors for stroke in patients with chronic 
kidney disease. J Vasc Interv Neurol. 2009;2(1):12631.

25. Iseki K, Fukiyama K. Clinical demographics and long term prognosis aftrer stroke in patients on chronic hemodialysis. Nephrol Dial Transpl. 2000;15(11):1808-13.

26. Mikolasevic I, Zutelija M, Mavrinac V, Orlic L. Dyslipidemia in patients with chronic kidney disease: etiology and management. Int JNephrol Renovasc Dis. 2017;10:35.

27. Cherzog CA, Asinger RW, Berger AK, Charytan DM, DiezJ, HartRG, Eckardt KU, KasiskeBL, McCullough PA, Passman RS, DeLoach SS. Cardiovascular disease in chronic kidney disease. A clinical update from Kidney Disease: Improving Global Outcomes (KDIGO). Kidney Int. 2011;80(6):572-86.

28. Abramson JL, Jurkovitz CT, Vaccarino V, Weintraub WS, Mcclellan W. Chronic kidney disease, anemia, and incident stroke in a middle-aged, communitybased population: the ARIC Study. Kidney Int. 2003;64(2):610-5.

29. Del-Fabbro P, Jean CL, Emmanuel C, Patrik M, Burnier M, Bernard B. Anemia and chronic kidney disease are potential risk factors for mortality in stroke patients: a historic cohort study. BMC Nephrology. 2010;11(1):27.

30. Johnson RJ, Nakagawa T, Jalal D, Sanchez-Lozada LG, Kang DH, Ritz E. Uricacid and chronic kidney disease: which is chasing which?Nefrol Dial Transplant. 2013;28(9):2221-8.
31. Falsetti L, Capeci W, Tarquinio N, Viticchi G, Silvestrini M, Catozzo V, dkk. Serum uric acid, kidney function and acute ischemic stroke outcomes in elderly patients: a single-cohort, perspective study. NeurolInt. 2017;9(1):11-6.

32. Bos MJ, Koudstaal PJ, Hofman A, Breteler MM. Decreased glomerular filtration rate is a risk factor for hemorragic but not for ischemic stroke: the Rotterdam study. Stroke. 2007;38(12):3127-32.

33. Abramson JL, Jurkovitz CT, Vaccarino V, Weintraub WS, Mcclellan W. Chronic kidney disease, anemia, and incident stroke in a middle-aged, communitybased population: the ARIC Study. Kidney Int. 2003;64(2):610-5.

34. Yang F, Chou D, Schweitzer P, Hanon S. Warfarin in haemodialysis patients with artrial fibrillation: what benefit? Europace. 2010;12(12):1666-72.

35. Townsend RR. Stroke in chronic kidney disease: prevention and management. Clin J Am Soc Nephrol. 2008;3(Sup 1):S11-6.

36. Sozio SM, Amstrong PA, Coresh J, Jaar BG, Fink NE, Platinga LC, dkk. Cerebrovascular disease incidence, characteristics, and outcomes in patient initiating dialysis: the choice for healthy outcomes in caring for ESRD (CHOICE) study. Am J Kidney Dis. 2009;54(3):468-77.

37. Murray AM, Seliger S, Lakshminarayan K, Herzog CA, Solid CA.Incidence of stroke before and after dialysis Initiation in older Patient. J Am Soc Nephrol. 2013;24(7):1166-73. 